\title{
The Volatility-Variability Hypotheses Testing and Hedging Effectiveness of Precious Metals for the Indonesian and Malaysian Capital Markets
}

\author{
Robiyanto Robiyanto, ${ }^{1 *}$ Sugeng Wahyudi, and Irene Rini Demi Pangestuti ${ }^{3}$ \\ ${ }^{1}$ Faculty of Economics and Business, Satya Wacana Christian University, Salatiga, Indonesia \\ ${ }^{2,3}$ Faculty of Economics and Business, Universitas Diponegoro, Semarang, Indonesia
}

\begin{abstract}
This study evaluates the use of futures contracts for precious metals to hedge against stock market risks and their hedging effectiveness on the Indonesian Stock Exchange (IDX) and the Kuala Lumpur Stock Exchange (KLSE). This study found that gold was the most effective hedging instrument, since it produced the highest hedging effectiveness both on the IDX and the KLSE among the other precious metals. None of the hedged portfolios had a higher Sharpe's ratio than the unhedged one on the IDX; however, all the hedged portfolios on the KLSE had a higher Sharpe's ratio than the unhedged ones. Almost all the hedged portfolios could produce a higher Treynor's ratio than the unhedged portfolios, both on the IDX and the KLSE. In general, this study concluded that studying some precious metals could reduce the investment risk, which was shown through the variance produced by the smaller portfolios, while gold can improve the risk-adjusted performance.
\end{abstract}

Keywords: DCC-GARCH; hedging effectiveness; optimal hedge ratio; precious metals; risk adjusted returns

JEL classification: G10, G11, G15

* Corresponding author's e-mail: robiyanto@staff.uksw.edu 


\section{Introduction}

The Indonesian Stock Exchange (IDX) has grown rapidly in terms of its value and volume during the last decade, due to the increasing number of issuers and investors. This growth has created opportunities to invest and to make transactions on the IDX. Many global financial institutions or foreign investors have shown their awareness of this, and started doing investments and transactions on the IDX. Their actions have brought capital inflows to the capital market, and tended to increase the volatility of the IDX, since these types of investors are vulnerable towards the global financial market's condition. Based on the IDX's value of transactions during 20102015, as shown in Table 1, there has been an upwards trend, which has been followed by the increasing contributions of foreign investors on the IDX.

Based on the number of historical events which occurred and have been reflected on the IDX, major shocks to the global financial markets could make foreign investors pull out their capital, which might

\section{Table 1. Recapitulation of Trading Value in IDX \\ (in Billion Rupiahs)}

\begin{tabular}{cccc}
\hline Period & $\begin{array}{c}\text { Trading } \\
\text { Value }\end{array}$ & \multicolumn{2}{c}{$\begin{array}{c}\text { Investors' } \\
\text { Contribution (\%) }\end{array}$} \\
\cline { 3 - 4 } & & Domestic & Foreign \\
\hline 2010 & $1,176,237.42$ & 68.28 & 31.72 \\
2011 & $1,223,440.51$ & 64.93 & 35.07 \\
2012 & $1,116,113.25$ & 57.46 & 42.54 \\
2013 & $1,522,122.36$ & 57.97 & 42.03 \\
2014 & $1,453,392.36$ & 59.42 & 40.58 \\
2015 & $1,406,367.63$ & 56.79 & 43.21 \\
\hline
\end{tabular}

Source:Capital Market Statistics published by Financial Services Authority cause a capital outflow, which would severely affect the capital market. This phenomenon needs serious action to reduce the investment risk, one solution is by creating a portfolio formulation which contains various asset classes, including precious metals.

Gold and some other precious metals like silver have often been viewed as safe haven assets for a long time. These precious metals have advantages, because of their durability, and can act as a hedge towards inflation (Beckmann and Czudaj 2012; Dee et al. 2013; Ghosh et al. 2004; Tkacz 2007; Worthington and Pahlavani 2007). Hammoudeh et al. (2010) even concluded that precious metals could also act as a hedge for exchange rates.

Researchers, academicians, and practitioners in finance began to pay greater attention to gold and other precious metals after the global financial crisis in 2008 (Baur and McDermott 2009; Baur and McDermott 2012). During that crisis period, in which the price of other instruments crashed, gold's price has shown a robustness, and has been relatively more stable compared to the other instruments. So, it is not surprising that researchers like Ibrahim and Baharom (2012) suggest that gold can act as a diversifier asset.

Many researchers like Arouri, Lahiani, and Nguyen (2014); Artigas et al. (2012); Conover et al. (2010); Kumar (2014) have started to scrutinize whether gold has the potential to be included in portfolio formulations. On the other hand, several researchers have given their attention to other precious metals, such as silver, platinum, and palladium e.g. Hammoudeh et al. (2010). Research conducted by Hammoudeh et al. (2010) tried to formulate a portfolio containing only precious metals, however the precious metals have their own various volatili- 
ties and correlations towards stock returns (Arouri et al. 2014), so it is important to formulate portfolios from precious metals and capital market instruments, such as stocks.

Since most research in Indonesia tends to use static portfolio formulation methods, such as Markowitz's model and the singleindex model among stocks only [e.g. Natalia et al. (2014); Sembiring (2012); Septyanto and Kertopati (2014); Triharjono (2013)], and does not incorporate other assets such as precious metals into the portfolios; this research will specifically investigate the role of precious metals on dynamic portfolio formulations, and their hedging effectiveness in the Indonesian capital market's setting. This study also investigates the role of precious metals on dynamic portfolio formulations and their hedging effectiveness in the Malaysian capital market's setting as a comparison, since precious metals have been known as an alternative investment, based on the culture and gold's attractiveness for Malaysian people, although the same condition also applies for Indonesia. Some research in Malaysia suggests that gold provides a diversification benefit to investors in the Malaysian market. Hence, gold could act as a diversifier for the Malaysian capital market (i.e. Ibrahim (2010); Ibrahim and Baharom (2012)) but none of this research has developed a theory for other assets such as precious metals in their portfolios, especially by using a dynamic portfolio formulation's approach.

\section{Conceptual Framework}

\section{Futures Trading in Indonesia}

Futures trading in Indonesia began officially on August 19, 1999 with the establishment of the Jakarta Futures Exchange.
There are several products traded on the Jakarta Futures Exchange such as foreign stock index futures, commodity futures, and currency futures. More than 20 futures brokers are operating in Indonesia. They offer various futures products such as soft commodity futures (i.e. oil, rubber etc.) and hard commodity futures such as industrials and precious metals (i.e. gold, silver, platinum and palladium). Different from other futures markets, which use futures prices as the underlying price, hard commodity futures trading in Indonesia uses the spot price as its underlying price. There are also two currency types used in Indonesian futures trading, they are the floating rate (follows the exchange market rate/investors using US\$ in their futures trading) and the fixed rate (investors use rupiah in their futures trading by assuming US\$ $1=\operatorname{Rp} 10,000)$.

\section{Futures Trading in Malaysia}

Futures trading in Malaysia can be performed on the Bursa Malaysia Derivatives Berhad (BMD) which is the only futures exchange in Malaysia. The BMD is owned by Bursa Malaysia Berhad, which owns 75 percent of it, and the Chicago Mercantile Exchange (CME) has the other 25 percent. Futures trading in Malaysia, for some products such as CPO or precious metals, can be done in the local currency with a maturity, or denominated in US\$ as in futures trading in Indonesia (depending on the broker hired).

\section{Precious metals as a hedge}

Baur and Lucey (2010) define a hedge as an asset that has no correlation or is negatively correlated to other assets or portfolios. Research conducted by Faubert (2012); Hillier et al. (2006); Hood and Malik (2013); Kaliyamoorthy and Parithi (2012) proved that gold has an ability to become a hedge for 
stock markets. In the emerging markets, Ghazali et al. (2016) found that gold could act as a hedge for the Malaysian capital market.

Among its other physical assets, gold is more durable, universally accepted, and can be transacted easily (Kumar2014). Silver is another precious metal that is also often classified as an investment instrument. However, the investment demand on silver is not as high as the one on gold. Radetzki (1989) stated that the investment demand on silver is only about 11 percent of the overall demand for silver as an investment asset. Hillier et al. (2006) noted that silver is generally obtained through mining, which is the same way as gold is obtained. According to the GFMS (2016), approximately 80 percent of the world's supply of silver came from mining activities in 2016. Hence, it is not surprising that the silver price is strongly interrelated to the gold price. Platinum is also extracted together with other metals, especially palladium. Mostly, the demand for platinum comes from the automobile industry, where it is used as a catalytic converter. From the total demand for platinum, only 10 percent of it is used for investment.

Arouri et al. (2014) argued that, recently, gold and other precious metals started to get attention from researchers, academicians, and practitioners in the financial field. This trend occurred because investors want to hedge their assets with other asset classes, such as precious metals, in order to minimize their investment risk in the stock markets. In addition, gold and other precious metals started to emerge as interesting alternative investment instruments, due to their different volatilities and weak correlations with stock returns.

\section{Precious metals as a portfolio instrument}

According to Baur and Lucey (2010), precious metals, especially gold, can act as a diversifier if they are positively (but not perfectly) correlated with another asset or portfolio on average. Some findings also conclude that gold can significantly improve an investment portfolio. Ratner and Klein (2008) found that the performance of an internationally diversified equity portfolio can be improved by including gold as a portfolio instrument. Research conducted by Chua et al. (1990) on the Toronto Stock Exchange (TSE) also found that investors can count on gold as a meaningful investment for portfolio diversification. This conclusion has also been supported by Hoang et al. (2015) who did their research on the Paris Stock Exchange. However, gold tends to underperform equities as a stand-alone investment (Herbst 1983). Consistently, Agyei-Ampomah et al. (2013); Hillier et al. (2006) found that investment portfolios that contain precious metals can significantly outperform all equity portfolios, because precious metals have unique characteristics such as a high hedging capability during periods of turbulence, and a low correlation with equity index returns. AgyeiAmpomah et al. (2013) conducted their research in the US, the UK, the EMU, and ten eurozone countries, while Hillier et al. (2006) performed their research by using the S\&P500 index as a proxy for the US market and the MSCI Europe/Australasia/Far East (EAFE) index as a proxy of the overall conditions of overseas markets.

Arouri et al. (2014) who conducted research into China's market setting, suggests that adding precious metals (i.e. gold) to a portfolio of stocks can improve its risk-ad- 
justed return and effectively hedge-in portfolios of stocks over time. While on the Indian market, Kumar (2014) found that the stock-gold portfolio has better diversification benefits than pure stock portfolios, and gold can improve the risk-adjusted performance of a well-diversified portfolio of stocks.

In the ASEAN setting, Do, Mcaleer, and Sriboonchitta (2009) found that gold could be a complement for stocks in Indonesia, Thailand, and Malaysia. Unfortunately, Do et al. (2009) did not formulate a portfolio which contains gold for these countries. In the Malaysian setting, Ghazali et al. (2013) concluded that holding a well-diversified portfolio, which contains gold, hopefully could provide reasonable returns and protection during economic turbulence, this same conclusion has also been drawn by Ibrahim (2012). Ibrahim (2012) found that gold could provide a diversification benefit for investors in the Malaysian market.

\section{Hedging effectiveness}

Johnson (1960) defined hedging effectiveness as a risk proportion which can be hedged. Since the effectiveness of the hedging needs to be measured; Ederington (1979) introduced a measurement concept for the effectiveness of the hedging. This concept has also attempted to be implemented into futures indices, as concluded by Figlewski (1984), in which the return of a fully hedged portfolio ought to be at the same level as that which can be obtained from risk-free interest, for the only risk available is the random one. Hedging focuses on risk elimination. The hedging effectiveness concept keeps evolving through time, like Howard and D'Antonio (1984) who introduced a hedging effectiveness measurement adapted from both the modern portfolio theory introduced by Markowitz (1959), and simplified and with a more applicable hedging effectiveness concept by $\mathrm{Ku}$ et al. (2007).

\section{Portfolio performance evaluation}

Before the modern portfolio theory was introduced by Markowitz (1959), investors would mostly observe a portfolio's performance based on its return only, and disregard the risk probabilities within. Thus, this modern portfolio theory becomes a very crucial foundation for the modern investment world. Investors, nowadays, have been equipped with all kinds of measurement instruments and concepts. They certainly facilitate the investors in keeping track and evaluating their investments' performance. Some well-known portfolio performance measurement tools are Sharpe's ratio (Sharpe 1966), Treynor's ratio (Treynor 1965), Jensen's Alpha (Jensen 1968), total risk alpha (Fama 1972) and the adjusted Sharpe's ratio (Pezier and White 2006).

Among those ratios, Sharpe's ratio has been widely accepted and implemented among the academicians and practitioners of finance, to measure the performance of a portfolio (Bednarek et al. 2014; Low and Chin 2013). It has even become an industry standard for measuring risk-adjusted returns (Kidd 2011), therefore it is seen as the measurement of a portfolio's performance which is most often cited by researchers in the portfolio management literature (Lo 2002). According to Kidd (2012), The simplicity and usefulness for comparing funds is the appeal of Sharpe's ratio, even when the benchmarks differ. The higher that Sharpe's ratio is, this indicates a better risk adjusted performance (Zulkafli et al. 2017). The advantage of Sharpe's ratio is that it makes it possible to rank the portfolios' performances (Scholz and Wilkens 2005). Another popular measurement is Treynor's ratio. Both ratios have been used for their ability to rank portfolios' perfor- 
mances and to check whether a portfolio is well diversified (Scholz and Wilkens 2006).

This study used Sharpe's ratio and Treynor's ratio to evaluate the portfolios' performances, because according to Pilotte and Sterbenz (2006), both Sharpe's ratio and Treynor's ratio can be based on either the exante or post-excess returns and standard deviations. The other reason is that both Jensen's Alpha and the total risk alpha have fatal disadvantages. Jensen's Alpha is heavily reliant on absolute measures of performance (Duda and Batyuk 2009). While Rudd and Clasing (1988) state "If a manager has a positive alpha, then it is easy to double it simply by doubling the active holdings. Hence, the alpha itself is a meaningless parameter." Scholz and Wilkens (2005) suggested that those disadvantages can be easily manipulated by means of leverage. Since the portfolios formed in this study were using derivatives that contain leverage, so those measurements were not fit to use in this study. Jensen's Alpha also prohibits the ranking of portfolios when the portfolios have different levels of exposure to the market. The adjusted Sharpe's ratio was not employed in this study because the portfolios' data were normally distributed (checked by a data normality test).

\section{Sharpe's ratio (variability based adjusted return) and Treynor's ratio (volatility based adjusted return)}

Two major concepts related to the measurement of portfolio performance were developed using the risk adjusted return, i.e. Treynor's ratio (Treynor 1965) and Sharpe's ratio (Sharpe 1966). Treynor (1965) proposed a method of assessing the fund manager's performance by considering the market's risk probability. Market risk ought to be seen as a serious issue. Treynor (1965) outlined that assets controlled by an investment manager should be considered as very liquid ones, which is certainly different with assets owned by a corporation. On that account, the fund manager could easily make decisions when dealing with investment policy in a market. Furthermore, his/her competitors (the other investment managers), would also definitely try to find opportunities to buy and sell securities on the same market. This competition would absolutely raise the market's risk probability, which might lead to trouble. Thus, the comparison and assessment of fund managers' performances are extremely necessary in the finance industry.

Treynor (1965) agreed that more than one risk existed in a diversified portfolio, i.e. a risk emerging due to market fluctuations, and the definite risk attached to certain securities. Those two kinds of risks could bring the following consequences:

1. The influence of the management level of investment returns, which usually also depends on the general condition of the market. Bullish and bearish market conditions would affect the portfolio. The more volatile a portfolio is, the better or worse it looks when it is compared to one with a lower volatility. This issue could not be solved by using the average of returns in a particular period, because the average return is mainly dominated by the availability of the trend.

2. Measuring the average of the returns would not easily avoid risk for the investors. Fluctuations occurring in one or two securities would certainly become a consideration for the investor. However, diversification might not be carried out when the risks are considered to be insignificant. Those different perceptions on risk, among different investors, make the absolute measurement of a portfolio's performance impossible to bring about. 
Therefore, Treynor (1965) created a more relative measurement by considering the various volatility levels of stock. Since precious metals could be a hedge for the stocks' volatility, so Treynor's ratio can grab the volatility reduction effectively, rather than the other measurement methods. Beside using Treynor's ratio, portfolio performance could also be measured with Sharpe's ratio, as formulated by Sharpe (1966). Sharpe (1966) developed Sharpe's ratio based on the theoretical framework of the modern portfolio theory, as suggested by Markowitz (1959). Encouraged by the mean variance model drawn by Markowitz (1959), Sharpe's ratio implemented a standard deviation of return as a systematic risk measurement instrument in the CAPM. Here, Sharpe's ratio scrutinizes the total risk while Treynor (1965) only looks at the systematic risk.

\section{Methods}

\section{Data}

The data used in this study were the monthly closing prices of the Composite Stock Price Index (CSPI) on the Indonesian Stock Exchange (IDX) and the Kuala Lumpur Composite Index (KLCI) for the Kuala Lumpur Stock Exchange (KLSE), and the gold price, silver price, platinum price, and palladium price on the international markets during January 1999 to July 2014. CSPI data were obtained from the IDX's monthly statistics while the data for the gold price, silver price, platinum price, and palladium price were obtained from www.kitco.com (provided by Kitco, a prominent Canadian precious metals company with a global scope of operation). The data from www.kitco.com are extensively quoted in international publications, both academically and practically i.e.
Brown et al. (2000); Ferojuddin and Ramani (2014); Picard (2015).

The CSPI's and KLCI's returns were calculated by using this following formula: Index $\operatorname{Return}_{t}=\left(\operatorname{Index}_{t}-\operatorname{Index}_{t-1}\right) /$ Index $_{t-1}$, with Index $x_{t}$ being the monthly closing price of the CSPI or KLCI in month $t$ and Index ${ }_{t-1}$ the monthly closing price of the CSPI or KLCI in month $\mathrm{t}-1$. Meanwhile the precious metals' returns were calculated by this following formula: PM Return $=\left(\mathrm{PM}_{\mathrm{t}}-\mathrm{PM}_{\mathrm{t}-1}\right) /$ $P M_{t-1}$, where $P M_{t}$ are the precious metals' closing prices (gold, silver, platinum and palladium) in month $\mathrm{t}$ and $\mathrm{PM}_{\mathrm{t}-1}$ are the precious metals' closing prices (gold, silver, platinum and palladium) in month $\mathrm{t}-1$. The risk-free rate used in this study was Bank Indonesia's (BI) rate for the Indonesian capital market and Malaysia's 10-year Government Bond Yield for the Malaysian capital market. The $\mathrm{BI}$ rate usage, as the risk-free rate for the portfolio construction in Indonesia, was also done by Lontoh and Anggono (2014). The BI rate data were obtained from the Indonesian Economic Financial Statistics, published by Bank Indonesia. While the Malaysian Government's Bond Yield was used as a proxy of the risk-free rate which was also affirmed by Thillainathan (1996), who mentioning it as a riskless yield and by Heng et al. (2005), and also by Fen et al. (2014). The Malaysian Government's Bond Yield data were obtained from Bloomberg.

\section{DCC-GARCH}

The DCC-GARCH model was introduced by Engle (2002) as a development of the GARCH model which was introduced by Bollerslev (1986). The DCC-GARCH model accommodates a time varying conditional correlation matrix with this following formula:

$\mathrm{P}_{\mathrm{t}}=\left(\operatorname{diag}\left(\mathrm{Q}_{\mathrm{t}}\right)\right)^{-1 / 2} \mathrm{Q}_{\mathrm{t}}\left(\operatorname{diag}\left(\mathrm{Q}_{\mathrm{t}}\right)\right)^{-1 / 2}$ 
Where $Q_{t}=\left(q_{t}^{i j}\right)$ is a symmetric positive definite matrix and is given by:

$\mathrm{Q}_{\mathrm{t}}=(1-\alpha-\beta) \overline{\mathrm{Q}}+\alpha \eta_{\mathrm{t}-1} \eta_{\mathrm{t}-1}^{\prime}+\beta \mathrm{Q}_{\mathrm{t}-1}$

In this equation, $\alpha$ and $\beta$ are non-negative scalars and it is assumed that $\alpha+\beta<1$, and $\bar{Q}$ is a (2X2) matrix of the unconditional correlation of the standardized errors $\eta_{t}$. The conditional variances are specified as univariate GARCH $(1,1)$ processes. Since the process of $\sigma_{t}^{2}$ is stationary, the GARCH $(1,1)$ process is enough to produce the process (Posedel 2005). Engle (2002) indicated that the specification of the DCC structure presents no obstacle to the model's estimation.

After the DCC was calculated, the next step was to calculate the optimal proportion and hedging ratios as suggested by Kroner and $\mathrm{Ng}$ (1998), by using this following formula:

$\mathrm{w}_{\mathrm{t}}^{\mathrm{PMs}}=\frac{\mathrm{h}_{\mathrm{t}}^{\mathrm{s}}-\mathrm{h}_{\mathrm{t}}^{\mathrm{sPM}}}{\mathrm{h}_{\mathrm{t}}^{\mathrm{s}}-2 \mathrm{~h}_{\mathrm{t}}^{\mathrm{sPM}}+\mathrm{h}_{\mathrm{t}}^{\mathrm{PM}}}$

Where $h_{t}^{\text {PM }}, h_{t}^{5}$, and refer respectively to the conditional volatility of the precious metals' returns, the conditional volatility of the CSPI's return, and the conditional covariance between the precious metals' return and the CSPI's return at time $t$.

Hedging effectiveness across the constructed portfolios can be assessed by examining the realized Hedging Effectiveness (HE) which had been formulated by $\mathrm{Ku}$ et al. (2007). Johnson (1960) defined hedging effectiveness as the proportion of the risk which could be hedged. Since Johnson (1960) did not show how the hedging effectiveness could be operated, so Ederington (1979) formulated hedging effectiveness as:
$\mathrm{HE}=1-\frac{\text { Variance }_{\text {hedged }}}{\text { Variance }_{\text {un hedged }}}$

Later $\mathrm{Ku}$ et al. (2007) revised the hedging effectiveness formulated by Ederington (1979).

The hedging effectiveness formulated by $\mathrm{Ku}$ et al. (2007) is as follows:

$\mathrm{HE}=\frac{\text { Variance }_{\text {unhedged }}-\text { Variance }_{\text {hedged }}}{\text { Variance }_{\text {unhedged }}}$

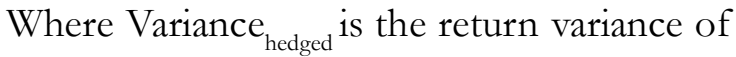
the stock market-precious metals portfolio, and Variance ${ }_{\text {unhedged }}$ is the return variance of the stock market portfolio. So, the higher the $\mathrm{HE}$ ratio, the more effective the hedging is in terms of the portfolios' variance reduction.

Meanwhile the optimal hedge ratio could be expressed as (Kroner and Sultan 1993):

$$
\beta_{t}^{\mathrm{PMs}}=\frac{\mathrm{h}_{\mathrm{t}}^{\mathrm{sPM}}}{\mathrm{h}_{\mathrm{t}}^{\mathrm{PM}}}
$$

Where $\beta_{t}^{\text {PMs }}$ is the optimal hedge ratio $h_{t}^{\text {PM }}$ and $h_{t}{ }^{\text {SPM }}$ and are respectively the conditional volatility of the precious metals' return and the conditional covariance between the precious metals' return and the stock market's return at time $t$.

According to research undertaken by Arouri et al. (2014), there is a tendency that the higher the optimal portfolio weight is, then the higher the optimal hedge ratio is.

In order to calculate the portfolio's return, this following formula was applied:

Portfolio Return ${ }_{t}=$

Portofolio value at time t-Portofolio value at time t-1

Portofolio value at time $\mathrm{t}-1$ 
Risk adjusted return measurements, i.e. Sharpe's ratio (variability based adjusted return) and Treynor's ratio (volatility based adjusted return), were used to assess the portfolio's performance. Sharpe's ratio was calculated by using this following formula (Sharpe 1966):

Sharpe's ratio $=$

Average Return of Portfolio - Risk Fee Rate

Standard Deviation of Portfolio

and Treynor's ratio was calculated by using this following formula (Treynor 1965):

Treynor's ratio $=$

Average Return of Portfolio - Risk Free Rate

Beta of Portfolio

\section{Empirical Results and Discussions}

\section{Unit Root Test Results}

Unit root tests were applied to test whether or not the data were stationary. These tests were conducted using an augmented Dickey-Fuller test as shown in Table 2. According to the unit root test results, it could be concluded that the data used in this study did follow a stationary process.

Table 2. Unit Root Test Results

\begin{tabular}{lcc}
\hline \multicolumn{1}{c}{ Variable } & $\begin{array}{c}\text { ADF Test } \\
\text { Statistics }\end{array}$ & Prob. \\
\hline CSPI & -10.83 & 0.00 \\
GOLD & -15.31 & 0.00 \\
SILVER & -14.49 & 0.00 \\
PLATINUM & -14.79 & 0.00 \\
PALLADIUM & -13.14 & 0.00 \\
\hline
\end{tabular}

Time-Varying Conditional Correlation between the CSPI's Return and the Precious Metals' Returns

The following Figure 1 shows the timevarying conditional correlation between the CSPI's return and the precious metals' return during the period from January 1999 to July 2014. While Figure 2 shows the time-varying conditional correlation between the KLCI's return and the precious metals' return during the period from January 1999 to July 2014

Those figures show that the time-varying conditional correlations between the CSPI's return and the precious metals' return, and also the KLCI's return and the precious metals' return had various patterns. It might be assumed that each of the precious metals had its own unique characteristics and could not be viewed as being similar to the others.

Both the time-varying conditional correlations of the CSPI's return-gold's return and the KLCI's return-gold's return depicted that, during the global financial crisis of 2008, the CSPI's return - gold's return and the KLCI's return - gold's return conditional correlations were negative (from 0.2 becoming 0.4 for the CSPI's return - gold's return and from 0.25 to -0.15 for the KLCI's return gold's return). This finding shows that gold could act as a safe haven for the IDX and KLSE. This finding is also consistent with previous research into the Malaysian capital market's setting, such as by Ibrahim (2010, 2012), who found that the gold market surged when faced with consecutive market declines in Malaysia, and this is consistent with Gürgün and Ünalmýs (2014) who found that gold could act as a strong safe haven for the Malaysian capital market. 
Figure 1. Time-Varying Conditional Correlation between CSPI Return and Precious Metal Returns (January 1999 - July 2014)
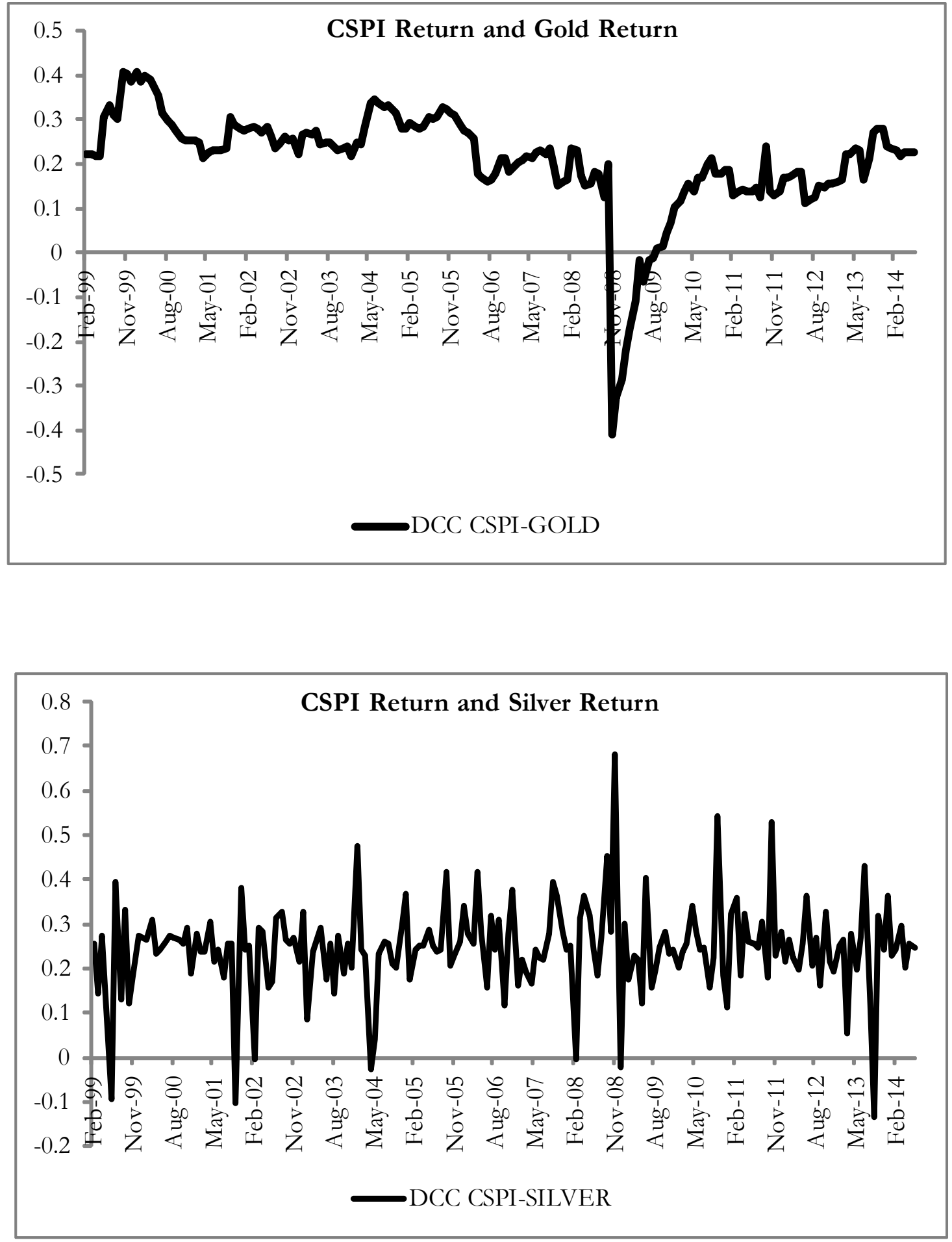
Figure 1. (Continued)
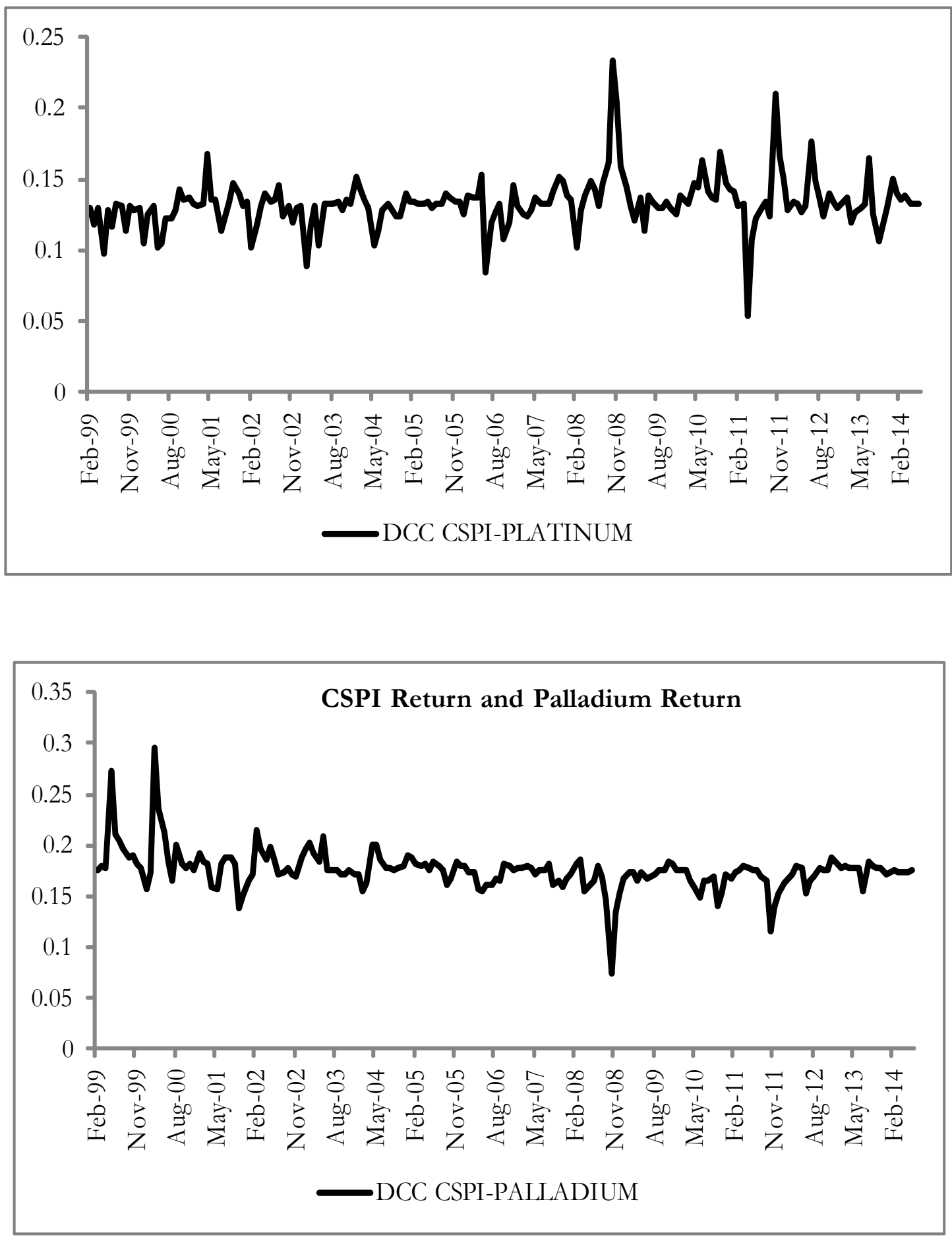
Figure 2. Time-Varying Conditional Correlation between KLCI Return and Precious Metal Returns (January 1999 - July 2014)
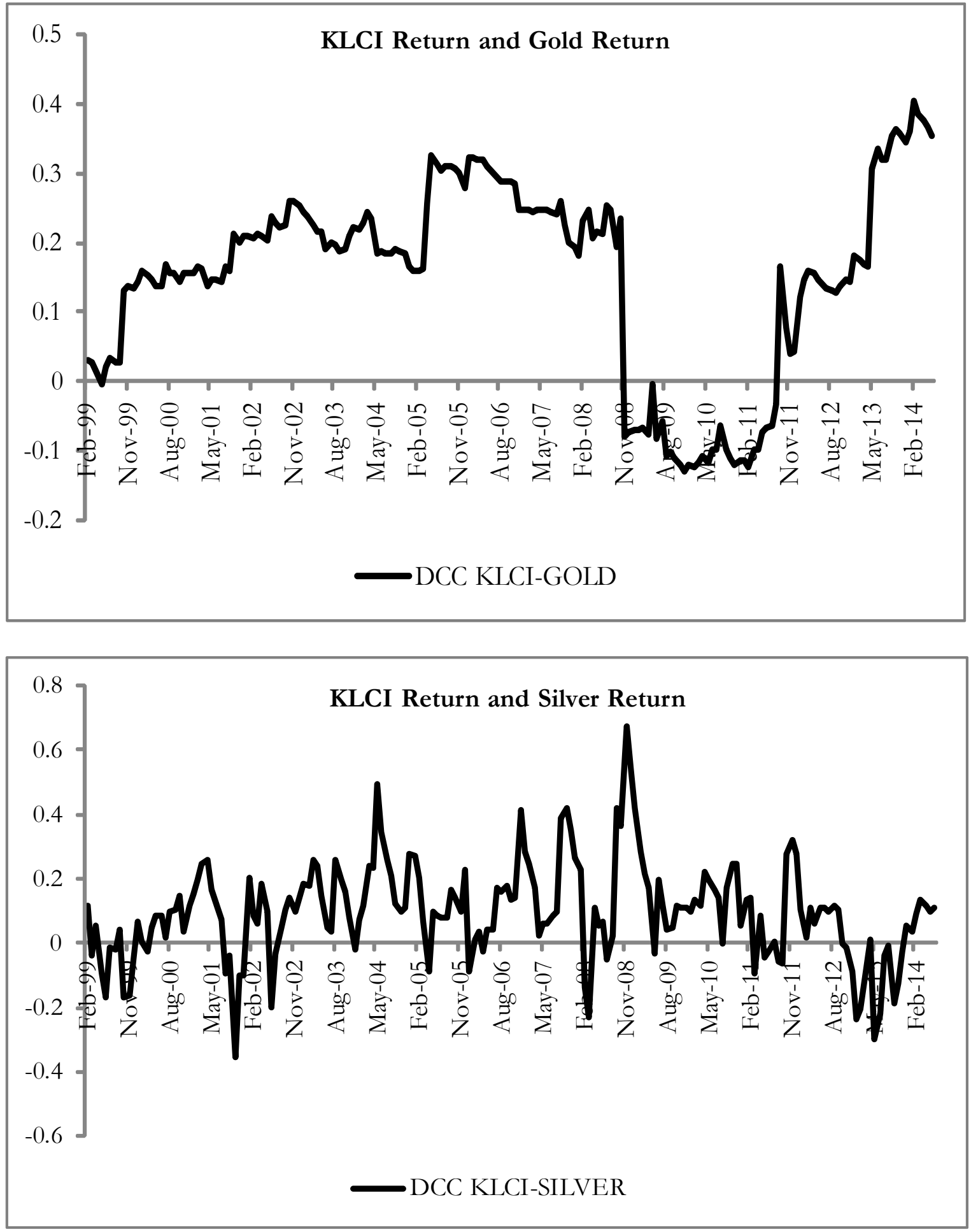
Figure 2. (Continued)
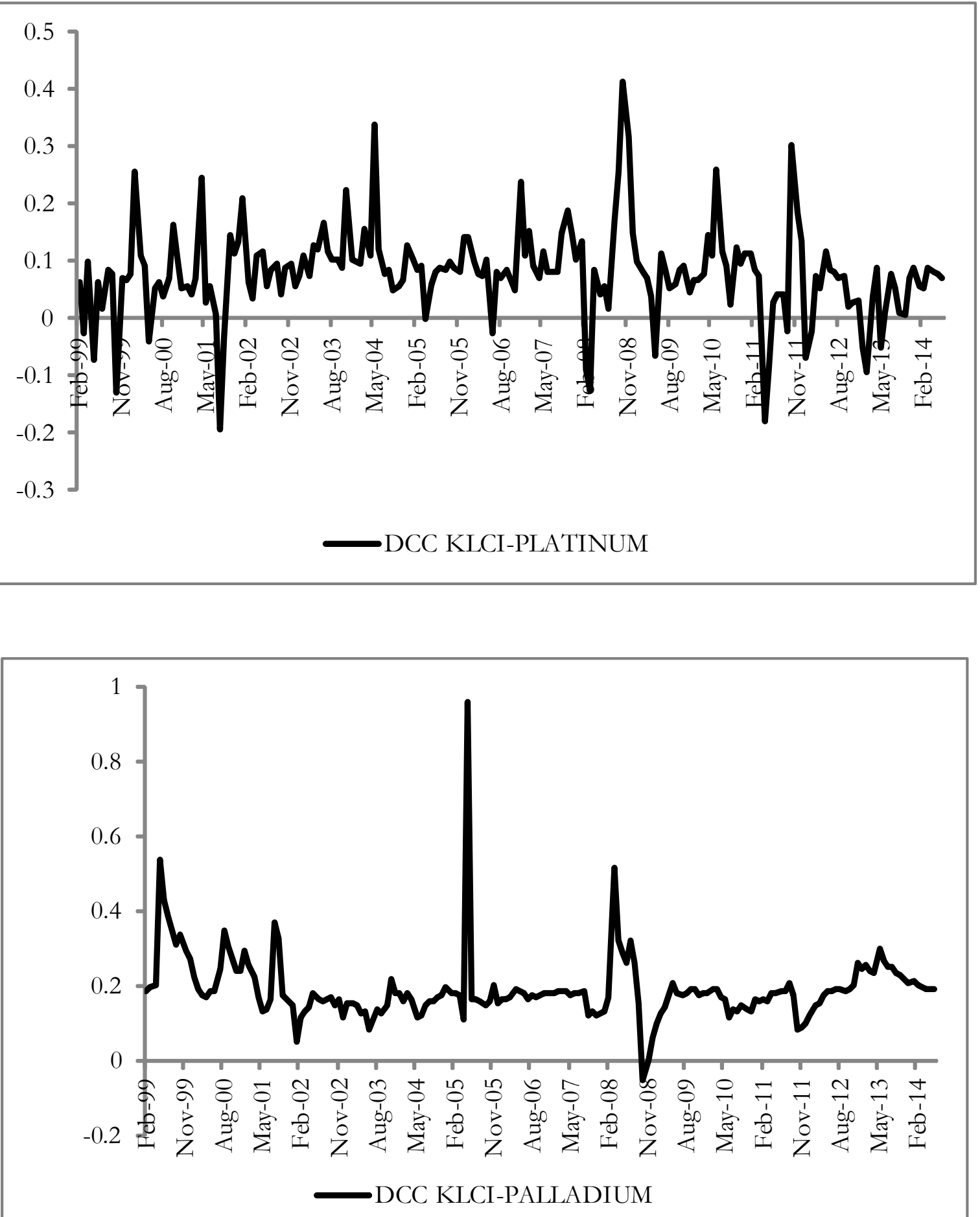
However, a different result was found in the time-varying conditional correlation of the CSPI's return -silver's return and the KLCI's return- silver's return, which showed that during the global financial crisis of 2008, the conditional correlation of the CSPI's return -silver's return and the KLCI's returnsilver's return tended to move inversely toward the conditional correlation of the CSPI's return -gold's return and the KLCI's returngold's return. During that period, the conditional correlation of the CSPI's return -silver's return and the KLCI's return- silver's return became positively stronger. In the 2008 preglobal financial crisis period, the conditional correlation of the CSPI's return -silver's return was around the 0.2 to 0.4 range and the conditional correlation of the KLCI's return and silver's return was around the -0.4 to 0.5 range, but during the global financial crisis of 2008, the conditional correlation of both the CSPI's return -silver's return and the KLCI's return- silver's return became 0.7. This finding explains that silver is considered to be an inappropriate safe haven for the IDX and KLSE.

On the other hand, the time-varying conditional correlation of the CSPI's return - platinum's return and the KLCI's return platinum's return showed a positive sign and tended to be stable at around the 0.05 to 0.24 range for the CSPI's return -platinum's return and around the -0.2 to 0.4 range for the KLCI's return- platinum's return. There was no significant movement of the conditional correlation of the CSPI's return and platinum's return, while a significant movement of the conditional correlation of the KLCI's return and platinum's return occurred. The conditional correlation of the KLCI's return and platinum's return became positively stronger during the global financial crisis of 2008. This could have happened be- cause platinum is also viewed as an industrial metal which can be affected by the industrial market's situation, especially in Malaysia.

A relatively similar result was also found with the time-varying conditional correlation of the CSPI's return - palladium's return and the KLCI's return - palladium's return. The conditional correlation between the CSPI's return and palladium's return had a positive sign and tended to be stable at around the 0.06 to 0.3 range during the observation period. While for the conditional correlation of the KLCI's return - palladium's return, this tended to be volatile around the 0.0 to 0.9 range during the observation period. Palladium is also viewed as one of the most popular industrial metals, so it is not surprising if the conditional correlation of the KLCI's return - palladium's return could also peak at the 0.9 level before the global financial crisis of 2008, and weaken to near the 0 level during the crisis. This shows that palladium could not act as a safe haven for both the IDX and the KLSE. This finding supports Krondahl and Lindahl (2012), who stated that palladium could not act as a safe haven and also supports Sari, Hammoudeh, and Soytas (2009) who concluded that it was highly unlikely that palladium could be classified as a safe haven.

\section{Optimal Portfolio Weight for the CSPI-Precious Metals and the KLCI- Precious Metals}

The time-varying optimal portfolio weights for the CSPI -precious metals and KLCI- precious metals are shown in Figure 3 and Figure 4 respectively, while the weights for the CSPI -precious metals and KLCIprecious metals are seen in Table 3. The average weight of gold in the CSPI-GOLD port- 
folio was 51.37 percent, while the average weights of silver, platinum, and palladium were 49.87 percent, 49.96 percent, and 49.99 percent respectively. While the average weight of gold in the KLCI-GOLD portfolio was 75.77 percent, and the average weights of silver, platinum, and palladium were 50.54 percent, 49.81 percent and 49.95 percent respectively.

Table 3. The Weight of CSPI and Precious Metals

\begin{tabular}{cccccc}
\hline \multirow{2}{*}{ Portfolio } & Weight & $\begin{array}{c}\text { GOLD } \\
\mathbf{( \% )}\end{array}$ & $\begin{array}{c}\text { SILVER } \\
\mathbf{( \% )}\end{array}$ & $\begin{array}{c}\text { PLATINUM } \\
\mathbf{( \% )}\end{array}$ & $\begin{array}{c}\text { PALLADIUM } \\
\mathbf{( \% )}\end{array}$ \\
\hline \multirow{3}{*}{ CSPI - GOLD } & Mean & 51.37 & - & - & - \\
& Minimum & 38.24 & - & - & - \\
& Maximum & 61.31 & - & - & - \\
\hline \multirow{3}{*}{ CSPI - SILVER } & Mean & - & 49.87 & - & - \\
& Minimum & - & 14.92 & - & - \\
& Maximum & - & 74.03 & - & - \\
\hline \multirow{3}{*}{ CSPI - PLATINUM } & Mean & - & - & 49.96 & - \\
& Minimum & - & - & 43.15 & - \\
& Maximum & - & - & 61.31 & - \\
\hline \multirow{3}{*}{ CSPI - PALLADIUM } & Mean & - & - & - & 49.99 \\
& Minimum & - & - & - & 39.66 \\
& Maximum & - & - & - & 57.45 \\
\hline
\end{tabular}

Figure 3. Time-Varying Optimal Portfolio Weight for CSPI and Precious Metals (January 1999 - July 2014)

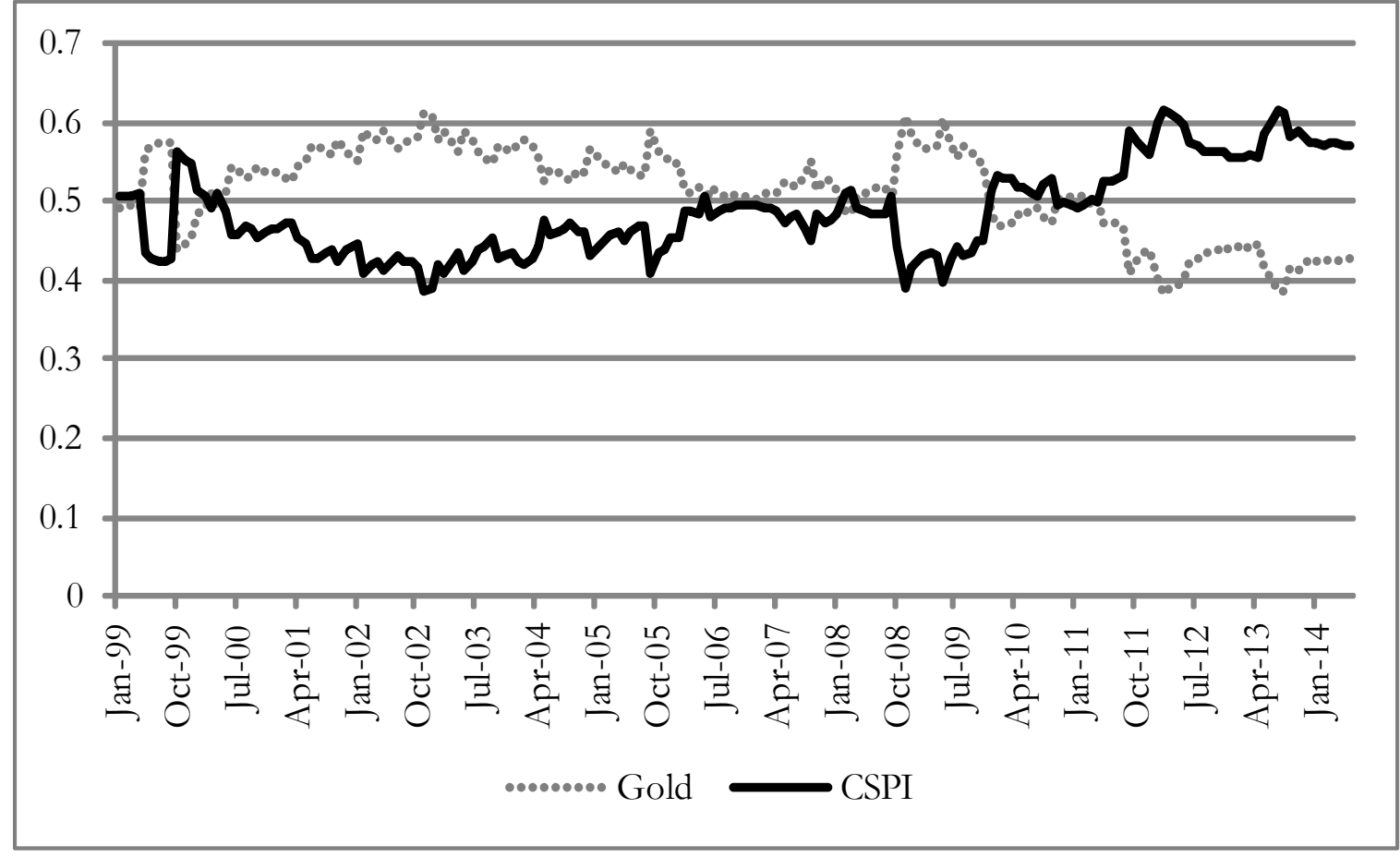


Figure 3. (Continued)
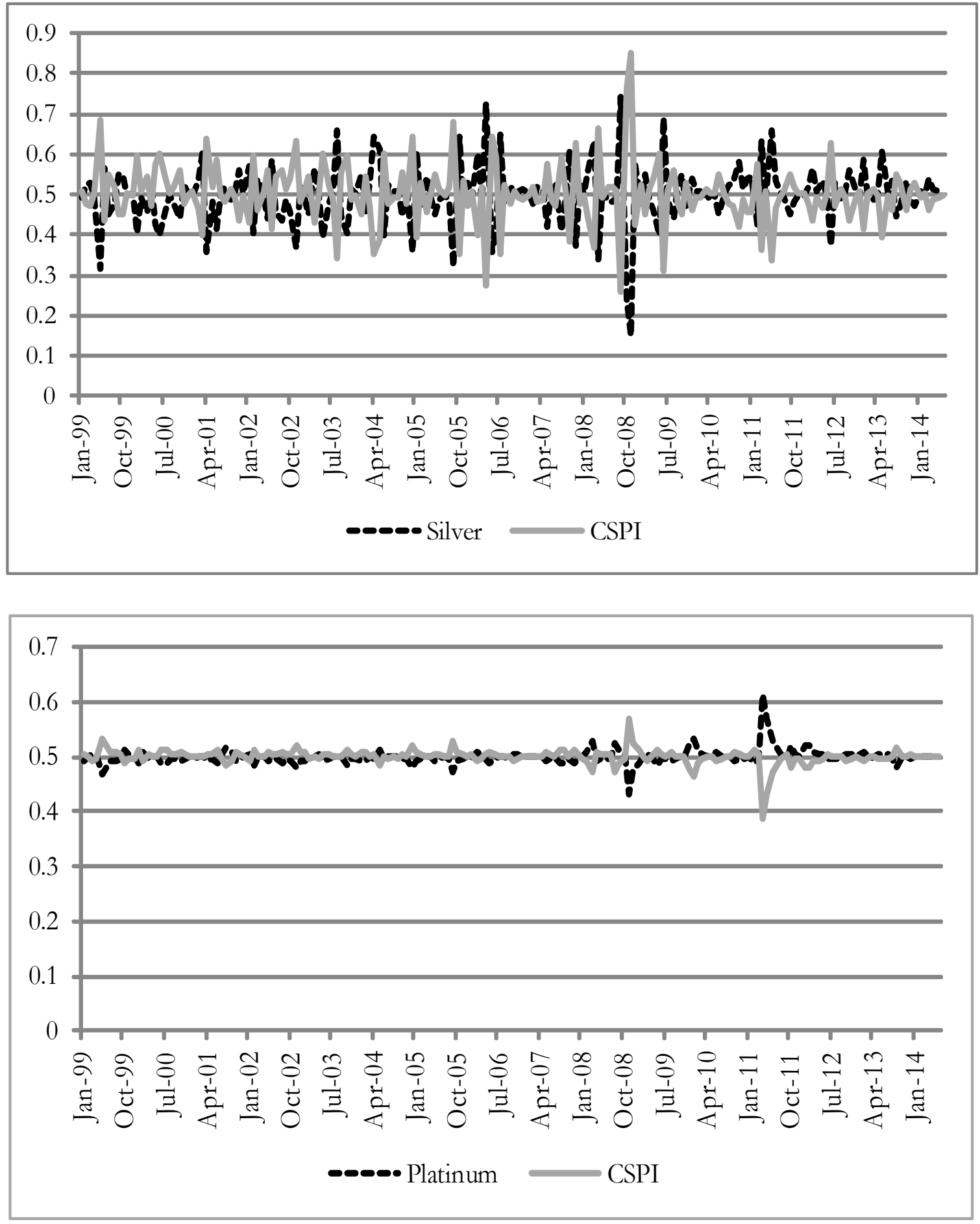
Figure 3. (Continued)

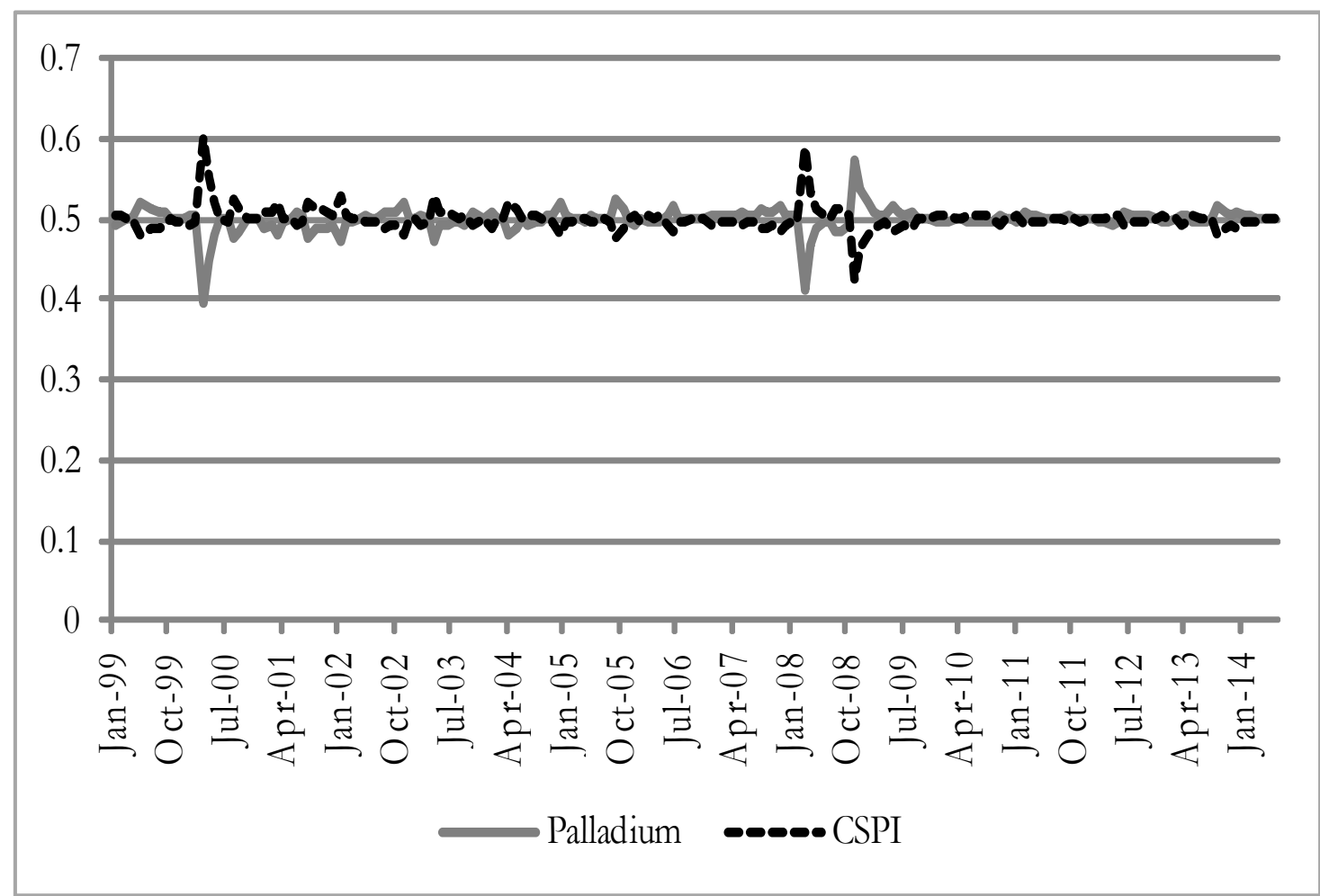

Figure 4. Time-Varying Optimal Portfolio Weight for KLCI and Precious Metals (January 1999 - July 2014)

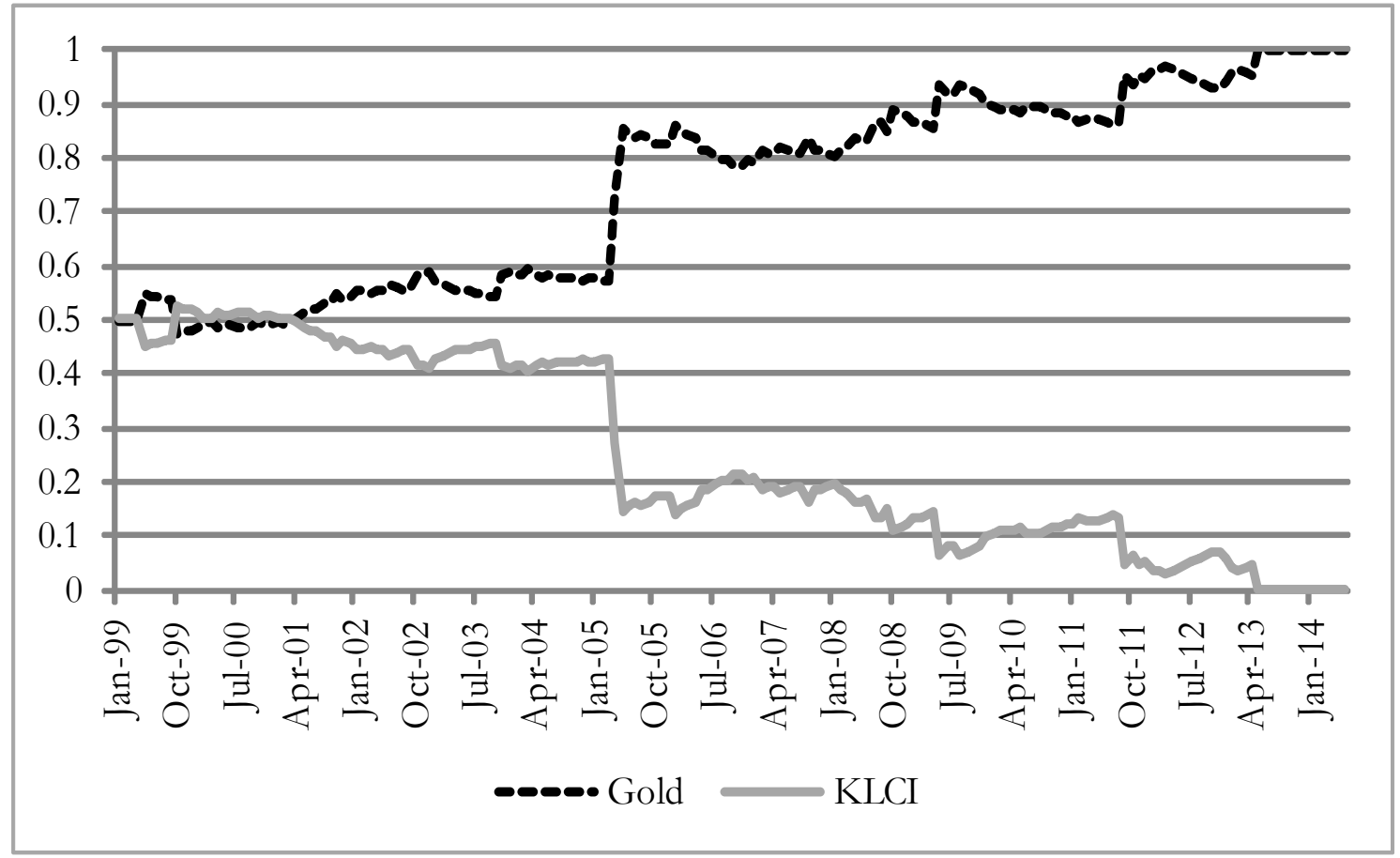


Figure 4. (Continued)
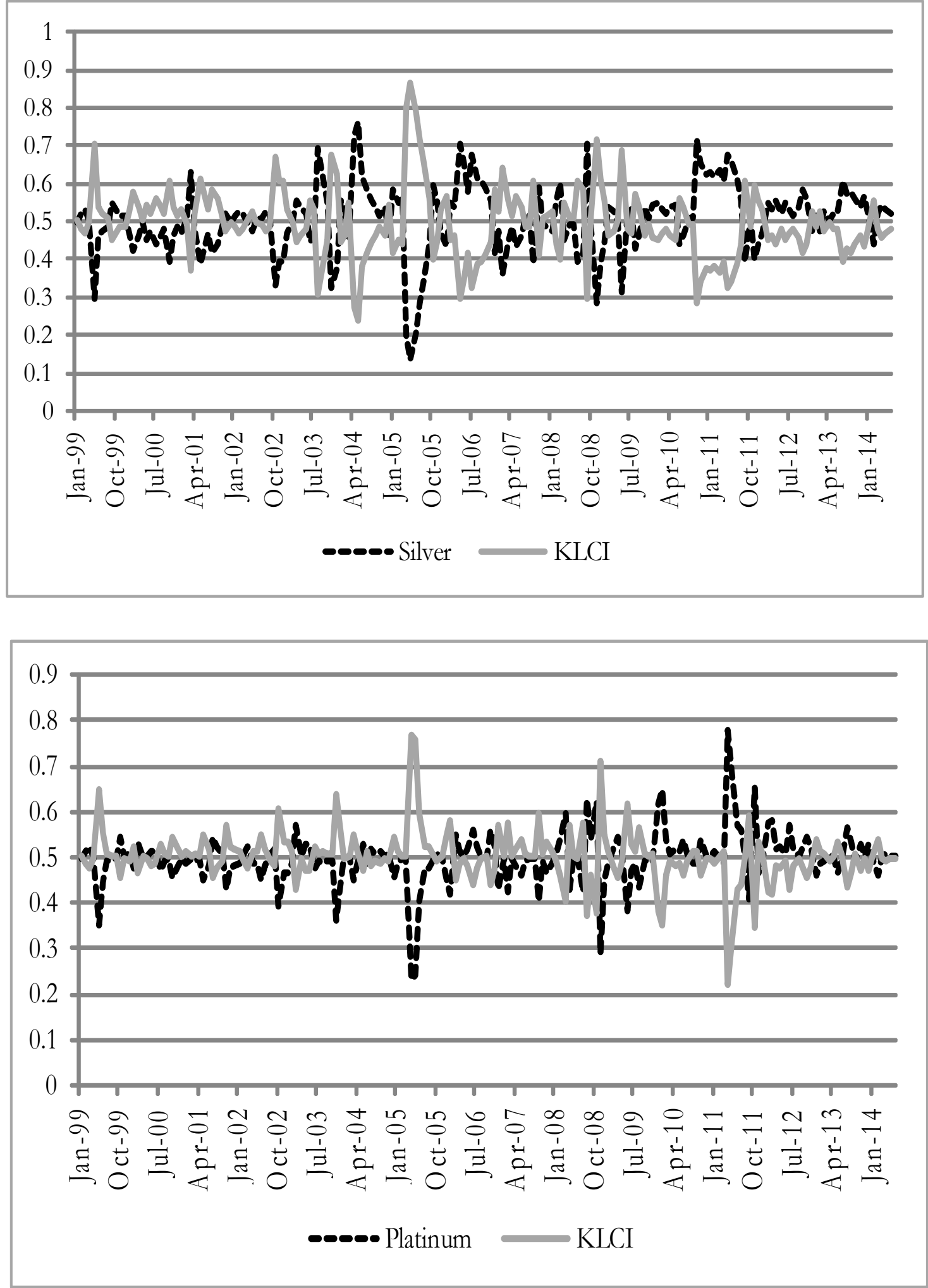
Figure 4. (Continued)

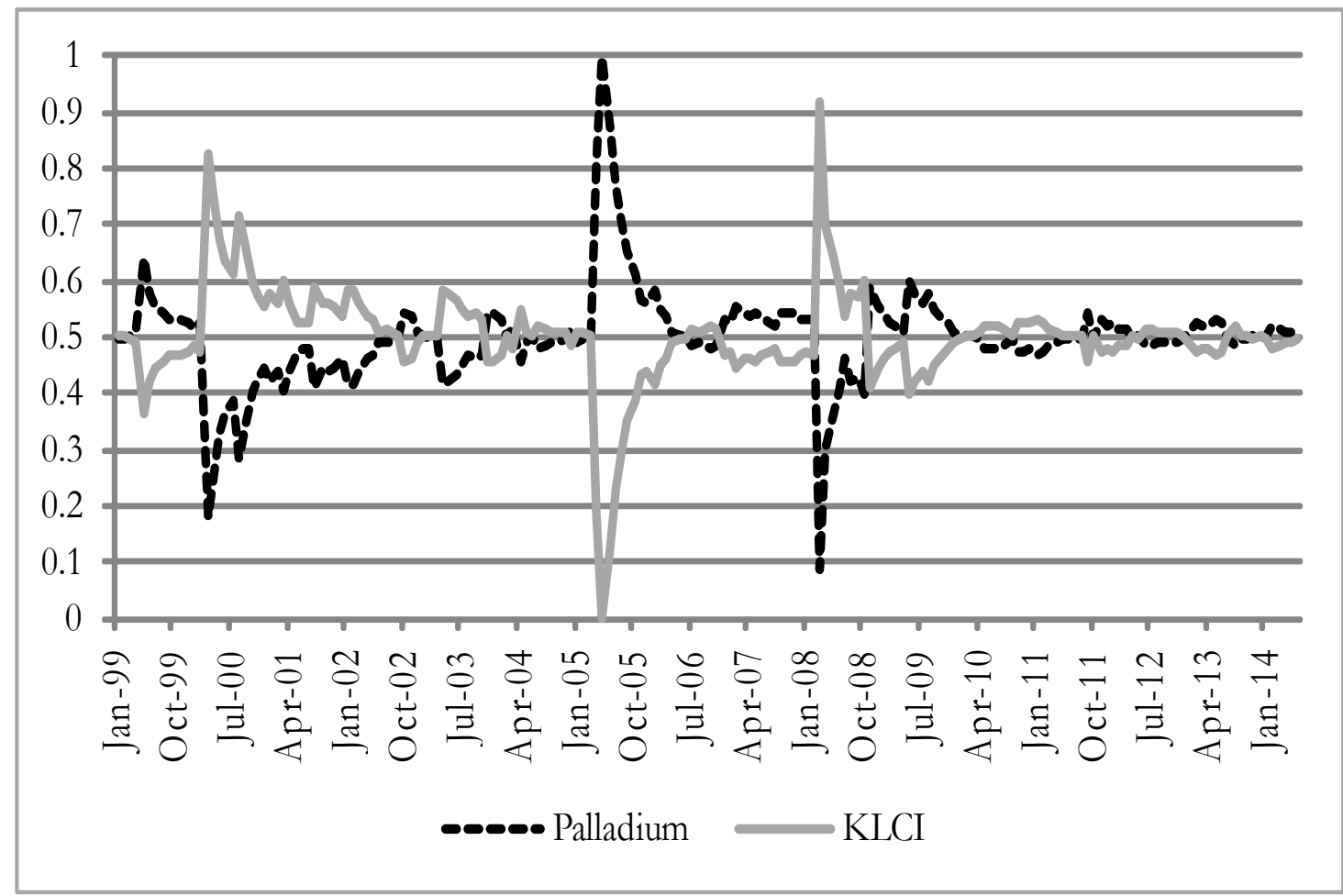

During the observation period, gold's weight in the CSPI-GOLD portfolio ranged from 38.24 percent to 61.31 percent, while the ranges of silver's weight, platinum's weight and palladium's weight in the portfolios which contained each of the precious metals were 14.92 percent to 74.03 percent, 43.15 percent to 61.31 percent and 39.66 percent to 57.45 percent respectively. While gold's weight in the KLCI-GOLD portfolio was from 47.50 percent to 100 percent, while the ranges of silver's weight, platinum's weight and palladium's weight in the portfolios which contained each of the precious metals were 13.42 percent to 75.98 percent, 23.08 percent to 77.86 percent and 8.47 percent to 100 percent respectively
Optimal Hedge Ratio, Hedging Effectiveness, Sharpe's Ratio and Treynor's Ratio

The optimal hedge ratio, the hedging effectiveness, Sharpe's ratio and Treynor's ratio for each instrument and portfolio are shown in the Table 4.

The CSPI - silver portfolio had the highest optimal hedge ratio on the IDX, which was 0.2474 . This optimal hedge ratio explains that, in order to hedge their stock investments on the IDX, investors should sell silver, worth IDR 0.2474 for every IDR 1 of their investment on the IDX. Gold's optimal hedge ratio was 0.2068 which meant that in order to hedge their stock investments on the IDX; 
investors should sell gold, worth IDR 0.2068 for each IDR 1 of their stock investment. Furthermore, the optimal hedge ratios for palladium and platinum were 0.1759 and 0.1333 respectively. For the KLSE, the KLCI - palladium portfolio had the highest optimal hedge ratio, which was 0.1922 . This optimal hedge ratio explains that in order to hedge their stock investment on the KLSE, investors should sell palladium worth MYR 0.1922 for every MYR 1 of their investment on the KLSE. The optimal hedge ratios for gold, silver and platinum for the KLCI were 0.1065; 0.0948; and 0.0815 respectively.

A portfolio comprising of the stocks on the IDX and precious metals could significantly reduce the investment risk. This could be seen from the hedging effectiveness, which was bigger than zero. The hedging effectiveness for the CSPI-GOLD was 0.5748, which could be interpreted that including gold in a portfolio could reduce the investment risk by 57.48 percent on the IDX. This could also be applied to other precious metals. Silver could reduce the investment risk by 18.39 percent on the IDX, while platinum and palladium could reduce the risk by 19.31 percent and 6.16 percent on the IDX respectively. These findings show that there is a tendency that, for the higher optimal portfolio weight, then the higher the optimal hedge ratio is. This conclusion is consistent with research done by Arouri et al. (2014) in China and Kumar (2014) in India. For the KLSE, only the KLCI-GOLD portfolio could produce a positive hedging effectiveness, while the other portfolios could not. The hedging effectiveness for the KLCI-GOLD was 0.3292 which could be interpreted as, by including gold into a portfolio, it could reduce the investment risk by 32.92 percent on the KLSE.

Sharpe's ratio for the CSPI-GOLD portfolio was 0.0909 . This value was lower than
Sharpe's ratio for the unhedged CSPI, which was 0.1053 . However, it was higher than the Sharpe's ratio for gold, which was 0.0175. It means that the CSPI-GOLD portfolio had a higher performance than the performance of gold. Unfortunately, this hedged portfolio could not exceed the unhedged portfolio when measured using the total risk/variability based adjusted return for the IDX. The same thing also happened to the other precious metals such as silver, platinum, and palladium. On the other hand, by using Treynor's ratio as the portfolios' performance measurement, which measures the systematic risk adjusted returns, the CSPI-GOLD, CSPIPLATINUM, and CSPI-Palladium portfolios all had a higher performance than the unhedged one. Individually, precious metals such as silver, platinum, and palladium had better systematic risk adjusted returns than the unhedged portfolio, and all the other hedged portfolios on the IDX.

However, for the KLSE, different results occurred. All the hedged portfolios formed from the KLSE had a better Sharpe's ratio (0.1266 for KLCI-GOLD; 0.1140 for KLCI-SILVER; 0.1080 for KLCI-PLATINUM; and 0.1097 for KLCI-PALLADIUM) compared to the Sharpe's ratio for the unhedged KLCI, which was 0.0790 and all the Sharpe's ratios for the precious metals (0.0175 for gold; 0.0360 for silver; 0.0036 for platinum; and 0.1000 for palladium). The same findings also apply for Treynor's ratio. All the hedged portfolios formed from the KLSE had better Treynor's ratios $(0.0152$ for KLCI-GOLD; 0.0114 for KLCI-SILVER; 0.0108 for KLCI-PLATINUM; and 0.0110 for KLCI-PALLADIUM) compared to the Treynor's ratio for the unhedged KLCI, which was 0.0045 and all the Treynor's ratios for the precious metals (0.0062 for gold; 0.0107 for silver; 0.0167 for platinum; and 0.0104 


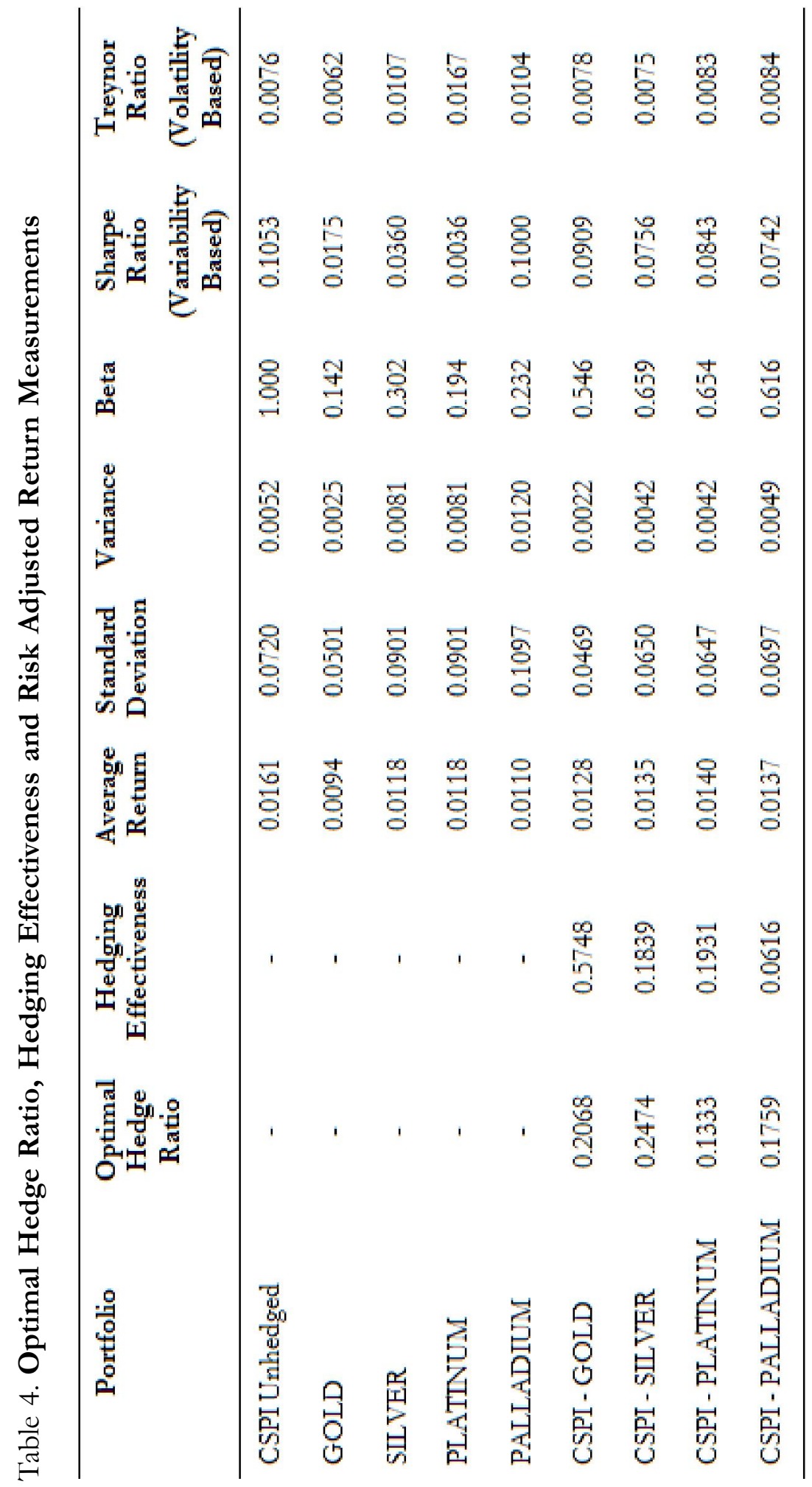


for palladium). Based on these results, it is clear that precious metals (i.e. gold) might be a reasonable investment for a diversified portfolio in the Malaysian capital market, and precious metals can improve the risk-adjusted performance of a well-diversified portfolio of stocks. These findings support Arouri et al. (2014); Ghazali et al. (2013); Herbst (1983); Ibrahim (2010); Ibrahim and Baharom (2012); Kumar (2014).

\section{Conclusion}

The purpose of this study was to investigate precious metals' role in portfolio formulation and their hedging effectiveness on the IDX and KLSE. This study found that gold is the precious metal that could earn the highest hedging effectiveness on both the IDX and the KLSE. In general, this study found that all the precious metals studied could reduce the investment risk, which was shown through the smaller hedged portfolios' variances, compared to the unhedged portfolios' variances. For the IDX, when the portfolios' performances were measured by Sharpe's ratio, which measures the total risk (variability based) adjusted returns, none of the hedged portfolios had a higher Sharpe's ratio than the unhedged ones. However, when the portfolios' performances were measured with Treynor's ratio, which measures the systematic risk (volatility based) adjusted return, then the CSPI-GOLD portfolio, the CSPIplatinum portfolio, and the CSPI-palladium produced higher Treynor's ratio values than the unhedged portfolios did. This finding shows that a hedged portfolio could give better protection from systematic risk rather than from total risk.
Consistent with some scholars' statements, this study also found that precious metals might enhance a portfolio's performance on the KLSE. The precious metals may also produce a more superior performance if they are included in stock portfolios on the KLSE.

The findings of this study could give several implications to fund managers, and risk related parties like risk managers. Fund managers must formulate an allocation strategy and stock/precious metals transaction strategy, which vary across time. To reduce the transaction costs in stock trading, fund managers and risk managers can adjust their portfolio's composition based on the incremental changes based on the portfolio's composition, as suggested in this study. In addition, they do not need to buy and sell precious metals in their physical form, but they can use the futures contracts.

Researchers, academicians, and practitioners can develop this study by applying the methods used to other instruments on the IDX, such as Shariah instruments which are represented by the Jakarta Islamic Index, bluechip stocks which are represented on the LQ45 Index, main board stocks which are represented by the MBX Index, and developed board stocks which are represented by the DBX Index. For the KLSE, there are the Kuala Lumpur Shariah Index (KLSI), FTSEBursa Malaysia Hijrah Shariah Index, Malaysia ACE, Malaysia Top 100, FTSE Malaysia and FTSE BM Mid 70. Moreover, other commodity market instruments can also be explored in order to scrutinize their potential benefits for portfolio formulation. 


\section{References}

Agyei-Ampomah, S., D. Gounopoulos, and K. Mzaouz. 2013. Does gold offer a better protection against soverign debt crisis than other metals. Paper presented at the EFMA.

Arouri, M. E. H., A. Lahiani, D. K. Nguyen. 2014. World gold proces and stock return in China: Insights for hedging and diversification strategies. Working Paper.

Artigas, J. C., J. Palmberg, B. Sederovich, and M. Grubb. 2012. Gold as a Strategic Asset for UK Investors. World Gold Council.

Baur, D. G., and B. M. Lucey. 2010. Is gold a hedge or a safe haven? An analysis of stocks, bonds and gold. The Financial Review, 45: 217-229.

Baur, D. G., and T. K. McDermott. 2009. Is gold a safe haven?: International evidence. Discussion Paper (310). Institute for International Integration Studies (IIIS).

Baur, D. G., and T. K. J. McDermott. 2012. Safe Haven Assets and Investor Behaviour Under Uncertainty. Institute for International Integration Studies.

Beckmann, J., and R. Czudaj. 2012. Gold as an Inflation Hedge in a time-varying coefficient framework. RUHR Economic Papers (362).

Bednarek, Z., P. Patel, and C. Ramezani. 2014. Sharpe ratio over investment horizon. Working Paper.

Bollerslev, T. 1986. Generalized autoregressive conditional heteroscedasticity. Journal of Econometrics 31: 307327. doi: https://doi.org/10.1016/0304-4076(86)90063-1.

Brown, L. R., M. Renner, and B. Halwell. 2000. Vital Signs 2000: The Environmental Trend That Are Shaping Our Future. New York: W.W. Norton \& Company. Inc.

Chua, J. H., G. Sick, and R. S. Woodward. 1990. Diversifying with gold stocks. Financial Analysts Journal 46 (4): 76-79.

Conover, C. M., G. R. Jensen, R. R. Johnson, J. M. Mercer. 2010. Is now the time to add commodities to your portfolio? Journal of Investing 4 (10-19).

Dee, J., L. Li, and Z. Zheng. 2013. Is gold a hedge or a safe haven? Evidence from inflation and stock market. International Journal of Development and Sustainability 2 (1): 1-16.

Do, G. Q., M. Mcaleer, and S. Sriboonchitta. 2009. Effects of international gold market on stock exchange volatility: Evidence from ASEAN emerging stock markets. Economics Bulletin 29 (2): 599-610.

Duda, K., and P. Batyuk. 2009. Performance and risk evaluation of Danish mutual and hedge funds. M.Sc. Thesis in Business Studies. University of Aarhus, Aarhus.

Ederington, L. 1979. The hedging performance of the new futures market. Journal of Finance 34: 157-170.

Engle, R. F. 2002. Dynamic conditional correlation: A simple class of multivariate generalized autoregressive conditional heteroskedasticity models. Journal of Business and Economic Statistics 20 (3): 339-350. doi: http://dx.doi.org/10.1198/073500102288618487.

Fama, E. F. 1972. Components of Investment Performance. Journal of Finance 27 (3): 551-567.

Faubert, V. 2012. Is gold still a safe haven? Tresor-Economics, Ministere de L'ÉEconomie Des Finances et de L'Industrie (April): 101.

Fen, A. B., L. S. Yee, L. C. Ling, O. C. Cher, and S. K. Yean. 2014. The determinants of Malaysia government bond yields from year 1996: Q1 to 2013: Q4. Thesis. Universiti Tunku Abdul Rahman. 
Ferojuddin, K., and L. Ramani. 2014. Empirical study of the relationship between spot price and future price od copper in MCX. Amity Business Review 15 (2).

Figlewski, S. 1984. Hedging performance and basis risk in stock index futures. Journal of Finance 39 (3): 657-669.

GFMS. 2016. World Silver Survey 2016. Retrieved from www.silverinstitute.org

Ghazali, M. F., H-H. Lean, and Z. Bahari. 2013. Is gold a hedge or a safe haven? An empirical evidence of gold and stocks in Malaysia. International Journal of Business and Society 14 (3): 428-443.

Ghazali, M. F., H-H. Lean, and Z. Baharia. 2016. Gold investments in Malaysia. Paper presented at the 2016 International Congress on Banking, Economics, Finance, and Business, Sapporo, Japan.

Ghosh, D., E. J. Levin, P. MacMillan, and R. E. Wright. 2004. Gold as an inflation hedge? Studies in Economics and Finance 22 (1): 1-25.

Gürgün, G., and I. Ünalmýs. 2014. Is gold a safe haven against equity market investment in emerging and developing countries? Finance Research Letters 11 (4): 341-348.

Hammoudeh, S. M., Y. Yuan, M. McAleer, M. A. Thompson. 2010. Precious metals-exchange rate volatility transmissions and hedging strategies. International Review of Economics and Finance 19: 633-647.

Heng, N. V., A. M. Nassir, M. Ariff, and S. Mohamad. 2005. Predictive power of forward rates: Evidence from Malaysian Government Securities (MGS) market. Investment Management and Financial Innovations 2: 61-71.

Herbst, A. 1983. Gold versus U.S. common stocks: Some evidence on inflation hedge performance and cyclical behavior. Financial Analysts Journal: 66-74.

Hillier, D., P. Draper, and R. Faff. 2006. Do precious metals shine? An investment perspective. Financial Analysts Journal 62 (3/4): 98-106.

Hoang, T.-H.-V., H-H. Lean, and W-K. Wong. 2015. Is gold good for portfolio diversification? A stochastic dominance analysis of the paris stock exchange. International Review of Financial Analysis.

Hood, M., and F. Malik. 2013. Is gold the best hedge and a safe haven under changing stock market volatility. Review of Financial Economic 22 (2): 47-52.

Howard, C. T., and L. J. D’Antonio. 1984. A risk-return measure of hedging effectiveness. Journal of Financial and Quantitative Analysis 19 (1): 101-112.

Ibrahim, M. H. 2010. Financial market risk and gold investment in an emerging market: the case of Malaysia. Paper presented at the PERKEM V.

Ibrahim, M. H. 2012. Financial risk market and gold investment in an emerging market: The case of Malaysia. International Journal of Islamic and Middle Eastern Finance and Management Research News 5 (1): 25-34.

Ibrahim, M. H., and A. H. Baharom. 2012. The role of gold in financial market: A Malaysian perspective. Economic Computation and Economic Cybernetics Studies and Research.

Jensen, M. 1968. The performance of mutual funds in the period 1945-1964. Journal of Finance 23: 389416.

Johnson, L. L. 1960. The theory of hedging and speculation in commodity futures. Review of Economic Studies 27 (3): 139-151.

Kaliyamoorthy, S., and S. Parithi, S. (2012). Relationship of Gold Market and Stock Market: An Analysis. International Journal of Business and Management Tomorrow, 2(6), 1-6. 
Kidd, D. 2011. The sharpe ratio and the information ratio. Investment Performance Measurement Feature Articles 1: $1-4$

Kidd, D. 2012. Risk-adjusted performance measures: A case study. Investment Risk and Performance 1: 1-4.

Krondahl, E., and O. Lindahl. 2012. Perceptual safe havens: A study of gold, oil, palladium, wheat, bonds, USD, and stocks. Degree Project Master of Science in Business and Economics. Lund University.

Kroner, K. F., and V. K. Ng. 1998. Modelling asymmetric comovements of assets returns. Review of Financial Studies 11 (4): 817-844.

Kroner, K. F., and J. Sultan. 1993. Time-varying distributions and dynamic hedging with foreign currency futures. Journal of Financial and Quantitative Analysis 28 (4): 535-551.

Ku, Y.-H. H., H-C. Chen and K-H. Chen. 2007. On the application of the dynamic conditional correlation model in estimating optimal time-varying hedge ratios. Applied Economics Letters 14 (7): 503509. doi: 10.1080/13504850500447331

Kumar, D. 2014. Return and volatility transmission between gold and stock sectors: Application of portfolio management and hedging effectiveness. IIMB Management Review 26 (1): 5-16. doi: 10.1016/ j.iimb.2013.12.002

Lo, A. W. 2002. The statistics of Sharpe ratios. Financial Analysts Journal 58 (4): 36-52.

Lontoh, A. D., and A. H. Anggono. 2014. The construction of optimal balanced fund consisting Indonesian stocks and bonds (Case study: LQ45 stocks and government bonds during period July 2009-June 2014). Journal of Business and Management 3 (3): 267-277.

Low, S.-W., and Y-B. Chin. 2013. Refinements to the Sharpe ratio --Evidence from Malaysian Equity Funds. GlobalEconomic Review 42 (1): 72-97. doi: http:/ /dx.doi.org/10.1080/1226508X.2013.769818.

Markowitz, H. M. 1959. Portfolio Selection: Efficient Diversification of Investments. New York: John Wiley \& Sons, Inc.

Natalia, E., Darminto, and M. G. Wi Endang NP. 2014. Penentuan portofolio saham yang optimal dengan model Markowitz sebagai dasar penetapan investasi saham (Studi pada perusahaan Food and Beverage yang terdaftar di Bursa Efek Indonesia tahun 2012). Jurnal Administrasi Bisnis 9 (1): 19 .

Pezier, J., and A. White. 2006. The relative merits of hedge fund indices and of funds of hedge funds in optimal passive portfolios. ICMA Discussion Papers in Finance.

Picard, J. 2015. Essays in high-frequency trading. Dissertation. Michigan State University, Michigan.

Pilotte, E. A., and F. P. Sterbenz. 2006. Sharpe and treynor ratios on treasury bonds. Journal of Business 79 (1): 149-180.

Posedel, P. 2005. Properties and estimation of GARCH (1,1) model. Metodoloski Zvezk 2 (2): 243-257.

Radetzki, M. 1989. Precious metals: The fundamental determinants of their price behaviour. Resources Policy 15 (3): 194-208.

Ratner, M., and S. Klein. 2008. The portfolio implications of gold investment. Journal of Investing 17 (1): 77-87.

Rudd, A., and H. K. Clasing. 1988. Modern Portfolio Theory - The Principles of Investment Management (2 ${ }^{\text {nd }}$ ed.): Orinda.

Sari, R., S. Hammoudeh, and U. Soytas. 2009. Dynamics of oils price, precious metal prices, and exchange rate. Energy Economics 32 (2): 351-362. 
Scholz, H., \& Wilkens, M. (2005). A Jigsaw Puzzle of Basic Risk-adjusted Performance Measures. Journal of Performance Measurement 57.

Scholz, H., and M. Wilkens. 2006. Investor-specific performance measurement - A justification of Sharpe ratio and Treynor ratio. Working Paper.

Sembiring, F. M. 2012. Analisis pembentukan portofolio optimal berdasarkan Single Index Model pada saham-saham yang dikelola oleh manajer investasi PT Panin Securities. Portofolio 9 (1): 1-17.

Septyanto, D., and B. Kertopati. 2014. Analisa pembentukan portofolio dengan menggunakan model markowitz dan single index model pada saham LQ45 di Bursa Efek Indonesia tahun 2009-2013. Working Paper.

Sharpe, W. F. 1966. Mutual fund performance. Journal of Business 39 (1): 119-138. doi: http://dx.doi.org/ $10.1086 / 294846$.

Thillainathan, R. 1996. Malaysia's bond market: The further reforms required to escape underdevelopment. ASEAN Economic Bulletin 13 (1): 95-113.

Tkacz, G. 2007. Gold prices and inflation. Working Paper (35). Bank of Canada.

Treynor, J. L. 1965. How to rate management of investment funds. Harvard Business Review 43 (1): 63-75.

Triharjono, S. 2013. Single Index Model sebagai alat analisis optimalisasi portofolio investasi saham (Studi kasus pada kelompok saham LQ-45 di BEI tahun 2009-2011). Jurnal Ilmu Manajemen and Bisnis 4 (1): 1-12.

Worthington, A. C., and M. Pahlavani. 2007. Gold investment as an inflationary hedge: Cointegration evidence with allowance for endogenous structural breaks. Applied Financial Economics Letters 3 (4): 259-262.

Zulkafli, A. H., Z. Ahmad, and E. Armal M. 2017. The performance of socially responsible investments in Indonesia: A study of the Sri Kehati Index (SKI). Gadjah Mada International Journal of Business, 19 (1): 59-76. doi: https://doi.org/10.22146/gamaijb.17959 
